\title{
Peningkatan Perilaku Hidup Bersih dan Sehat (PHBS) di Rumah Tangga Terhadap Penggunaan Air Sumur Gali dalam Menurunkan Angka Kejadian Water Borne Disease
}

\author{
Norsita Agustina ${ }^{1}$, Ridha Hayati ${ }^{2}$, Hilda Irianty ${ }^{3}$ \\ 1*. Universitas Islam Kalimantan MAAB Banjarmasin, Jl. Adhyaksa, Kota Banjarmasin, Indonesia, 70123 \\ 2. Universitas Islam Kalimantan MAAB Banjarmasin, Jl. Adhyaksa, Kota Banjarmasin, Indonesia, 70123 \\ 3. Universitas Islam Kalimantan MAAB Banjarmasin, Jl. Adhyaksa, Kota Banjarmasin, Indonesia, 70123 \\ *e-mail: norsita.agustina@gmail.com
}

\begin{abstract}
Abstrak
Pemberdayaan masyarakat merupakan proses yang harus dimulai dari rumah tangga atau keluarga. Rumah tangga atau keluarga yang sehat merupakan modal pembangunan bagi suatu Negara dimana modal tersebut perlu untuk dijaga, ditingkatkan dan dilindungi kesehatannya. Beberapa anggota rumah tangga mempunyai masa rawan terkena penyakit menular atau penyakit tidak menular, oleh karena itu untuk mencegah penyakit tersebut, anggota rumah tangga perlu diberdayakan untuk melaksanakan kegiatan perilaku hidup bersih dan sehat (PHBS) (Depkes, 2013). Tujuan yang diharapkan dari kegiatan ini adalah adanya perubahan Perilaku Hidup Bersih dan Sehat (PHBS) di rumah tangga dalam penggunaan air dan mengurangi resiko yang akan dialami bila tidak tepat mengkonsumsi air serta dapat melindungi diri dan keluarga mereka dari kejadian water borne disease yang kemungkinan dapat timbul dari konsumsi air tersebut. Manfaat adanya kegiatan pengabdian ini adalah mengarahkan pola pikir untuk lebih peduli terhadap Perilaku Hidup Bersih dan Sehat (PHBS) di rumah tangga, antisipasi untuk kesehatan keluarga mereka dan memahami dan mengenal kejadian water borne disease, pencegahan serta pengobatan. Metode yang dilaksanakan dalam kegiatan pengabdian ini adalah observasi, penyuluhan model PRA (Participatory Rural Appraisal) dan praktek dengan meggunakan media leaflet. Khalayak sasaran adalah warga yang memiliki sumur gali di Desa Pasayangan Barat Kabupaten Banjar. Dari hasil penyuluhan masyarakat merubah perilaku hidup bersih dan sehat dalam penggunaan air sumur gali dan masyarakat sudah mengetahui kualitas air sumur mereka dengan pemeriksaan laboraturium yang sebelumnya dilakukan pemeriksaaan. Pelaksanaan Penyuluhan ini dilaksanakan di Aula Kantor Kelurahan Pasayangan Barat dengan jumlah peserta 40 orang.
\end{abstract}

Kata Kunci : PHBS Rumah Tangga, Air, Water Borne Disease

\section{Pendahuluan}

Perilaku Hidup Bersih dan Sehat (PHBS) adalah upaya yang dari perorangan atau individu, keluarga, kelompok serta masyarakat untuk belajar dan menciptakan kondisi baru bagi diri mereka. Upaya tersebut dilakukan dengan cara membuka jalur komunikasi, memberikan informasi, serta melakukan edukasi. Hal tersebut dilakukan dengan tujuan untuk meningkatkan pengetahuan, merubah sikap dan merubah perilaku dari perorangan atau individu, keluarga, kelompok serta masyarakat. Lewat strategi promosi kesehatan yang ada, antara lain melalui pendekatan kepemimpinan, melalui bina suasana, serta melalui pemberdayaan masyarakat, diharapkan pada akhirnya masyarakat tersebut akan mampu mengenali, dan mampu untuk mengetahui masalah kesehatannya sendiri. Terutama pada tingkat rumah tangga, karena rumah tangga merupakan dasar dari bermasyarakat, maka dari rumah tangga diharapkan masyarakat dapat menerapkan cara-cara hidup bersih dan sehat (Depkes,2005).

Pemberdayaan masyarakat merupakan proses yang harus dimulai dari rumah tangga atau keluarga. Rumah tangga atau keluarga yang sehat merupakan modal pembangunan bagi suatu Negara dimana modal tersebut perlu untuk dijaga, ditingkatkan dan dilindungi kesehatannya. Beberapa anggota rumah tangga mempunyai masa rawan terkena penyakit menular atau penyakit tidak menular, oleh karena itu untuk mencegah penyakit tersebut, anggota rumah tangga perlu diberdayakan untuk melaksanakan kegiatan perilaku hidup bersih dan sehat (PHBS) (Depkes, 2013).

Air merupakan salah satu kebutuhan untuk mempertahankan hidup. Air bersih dapat berasal dari air sumur, air pipa, air telaga, air sungai dan mata air. Penduduk di negara kita masih banyak yang menggunakan air sumur untuk keperluan sehari-hari antara lain untuk mandi, cuci dan memasak (Mukono, 2002). Air bersih adalah air yang digunakan untuk keperluan sehari-hari yang kualitasnya memenuhi syarat kesehatan dan dapat diminum apabila telah dimasak (Peraturan Menteri Kesehatan RI No. 416/Menkes/Per/IX/1990). Ditinjau dari segi kualitas, air harus memenuhi beberapa syarat kesehatan baik fisik, bakteriologis, kimiawi maupun radioaktif (Keputusan Menteri Kesehatan RI 
No.907/Menkes/SK/VII/2002). Air merupakan sarana utama dalam meningkatkan derajat kesehatan masyarakat, karena merupakan salah satu media berbagai penularan penyakit, terutama penyakit saluran pencernaan. Penyakit saluran pencernaan dapat dikurangi melalui penyediaan air yang memenuhi syarat kualitas air bersih. Air merupakan salah satu di antara pembawa penyakit yang berasal dari tinja yang akhirnya akan sampai kepada manusia. Sampai saat ini penduduk Indonesia sulit terbebas dari penyakit diare, kolera, disentri hingga tifus. Sebab, semua penyakit tersebut berhubungan erat dengan air (waterborne diseases). Kasus penyakit diare sangat berkaitan dengan perilaku manusia, sarana air bersih, sarana pembuangan air limbah dan kesehatan lingkungan pada musim kemarau (Puspita, 2003).

Sumber air minum adalah sumber air yang akan digunakan oleh masyarakat untuk keperluan sehari-hari. Air adalah kebutuhan dasar untuk kehidupan manusia, terutama untuk digunakan sebagai air minum, memasak makanan, mencuci, mandi dan kakus. Ketersediaan sistem penyediaan air bersih merupakan bagian yang selayaknya diprioritaskan untuk memenuhi kebutuhan masyarakat baik di perkotaan maupun pedesaan. Hingga saat ini penyediaan oleh pemerintah menghadapi keterbatasan, baik sumber daya manusia maupun sumber daya lainnya (Devi, N, 2012).

Daerah Desa Pasayangan Barat Kabupaten Banjar mayoritas menggunakan air sumur gali untuk keperluan sehari-hari mereka, air sumur mereka kadang terlihat keruh atau tidak jernih ketika musim hujan tiba hal in terlihat bahwa kualitas fisik air sumur gali yang tidak memenuhi syarat yang biasanya dipengaruhi oleh keadaan. Perilaku masyarakat dengan penggunaan air bersih sangat kurang salah satunya mereka melaksanakan perilaku memasak air dengan cara yang tidak tepat, yaitu memasak air hingga mendidih namun tidak dibiarkan mendidih selama lebih dari 5 menit. Perilaku tersebut tidak tepat, karena dapat membunuh kuman patogen yang terdapat di dalam air yang akan mereka konsumsi cara yang efektif dalam memasak air adalah memasak atau merebus air yang akan kita konsumsi hingga mendidih. Cara ini sangat efektif untuk mematikan semua patogen yang ada dalam air seperti virus, bakteri, spora, fungi dan protozoa. Lama waktu air mendidih yang dibutuhkan adalah berkisar 5 menit, namun lebih lama lagi waktunya akan lebih baik, direkomendasikan selama 20 menit. Jadi masyarakat harus memperhatikan dan melaksanakan cara memasak air yang benar agar seluruh bakteri dalam air bersih tersebut mati sehingga layak untuk dikonsumsi dan dapat menurunkan angka kejadian water borne disease.

\section{Metode Pelaksanaan}

Pengabdian Masyarakat di Desa Pasayangan Barat ini dilaksanakan di Aula Kantor Kelurahan Pasayangan Barat. Metode pendekatan menggunakan model PRA (Participatory Rural Appraisal) atau penilaian masyarakat secara partisipatif. Metode Participatory Rapid Appraisal (PRA) atau penilaian masyarakat secara partisipatif dilakukan melalui berbagai kegiatan seperti pemetaan masalah yang dialami masyarakat terhadap konsumsi air, penyakit water borne diseases dan permasalahan yang terkait dengan topik keadaan, analisis keadaan yang berupa bagaimana kualitas air yang mereka ketahui dan identifikasi tentang perubahan-perubahan yang terjadi terhadap kualitas air. kegiatan pengabdian sepenuhnya dilakukan dengan cara aktif mengikutsertakan peserta dalam setiap topik yang dibicarakan dan diharapkan muncul banyak tanggapan dan pertanyaan dari peserta, sehingga diharapkan mampu menarik minat lebih tinggi dari peserta dan diharapkan ada perubahan sosial baik dari sisi masyarakat Desa Pasayangan Barat disamping pengabdian masyarakat merupakan kegiatan tri darma oleh dosen pada setiap perguruan tinggi.

Dalam kegiatan pengabdian masyarakat berbasis PRA di Desa Pasayangan Barat ini berlangsung dalam kurun waktu 2 minggu mulai tanggal 25 Oktober sampai dengan 04 Oktober. Kegiatan ini terlebih dahulu pemeriksaan kualitas air sumur gali (total coliform dan e.coli) agar masyarakat mengetahui bagaimana kualitas air yang mereka konsumsi. Dalam pengabdian masyarakat ini juga mempraktekan cuci tangan pakai sabun dalam hal ini salah satu merupakan indikator Perilaku Hidup Bersih

Tabel 1. kualitas Bakteriologis

\begin{tabular}{|r|l|l|l|l|l|l|}
\hline Sampel & $\begin{array}{c}\text { Pemeriksaan } \\
(\text { MPN } \\
\text { Coliform })\end{array}$ & $\begin{array}{c}\text { Batas } \\
\text { maksimum } \\
\text { diperbolehkan }\end{array}$ & Ket. & $\begin{array}{c}\text { Hasil } \\
\text { Pemriksaan } \\
\text { E.Coli }\end{array}$ & $\begin{array}{c}\text { Batas } \\
\text { maksimum } \\
\text { diperbolehkan }\end{array}$ & Ket \\
\hline Sampel 1 & $\geq 1898$ & & TMS & 46 & & TMS \\
Sampel 2 & 438 & & TMS & 7 & & TMS \\
Sampel 3 & $\geq 1765$ & & TMS & 46 & & TMS \\
Sampel 4 & 438 & TMS & 46 & & TMS \\
Sampel 5 & $\geq 1898$ & & TMS & 190 & TMS \\
Sampel 6 & $\geq 1765$ & TMS & 46 & & TMS \\
Sampel 7 & $\geq 1765$ & TMS & 46 & & TMS \\
Sampel 8 & 271 & TMS & 46 & & TMS \\
Sampel 9 & $\geq 1898$ & & TMS & 7 & & TMS \\
Sampel 10 & 438 & TMS & 7 & & \\
Sampel 11 & 271 & & TMS & 29 & &
\end{tabular}




\begin{tabular}{|c|c|c|c|c|c|c|}
\hline Sampel 12 & $\geq 1765$ & & TMS & 29 & & TMS \\
\hline Sampel 13 & $\geq 1765$ & & TMS & 7 & & TMS \\
\hline Sampel 14 & 438 & & TMS & 46 & & TMS \\
\hline Sampel 15 & 271 & & TMS & 190 & & TMS \\
\hline Sampel 16 & 76 & 50/100MPN & TMS & 46 & 0/100MPN & TMS \\
\hline Sampel 17 & 76 & & TMS & 190 & & TMS \\
\hline Sampel 18 & $\geq 1898$ & & TMS & 29 & & TMS \\
\hline Sampel 19 & $\geq 1898$ & & TMS & 46 & & TMS \\
\hline Sampel 20 & 438 & & TMS & 7 & & TMS \\
\hline Sampel 21 & $\geq 1765$ & & TMS & 7 & & TMS \\
\hline Sampel 22 & $\geq 1765$ & & TMS & 46 & & TMS \\
\hline Sampel 23 & $\geq 1898$ & & TMS & 190 & & TMS \\
\hline Sampel 24 & 190 & & TMS & 190 & & TMS \\
\hline Sampel 25 & 76 & & TMS & 46 & & TMS \\
\hline Sampel 26 & $\geq 1898$ & & TMS & 4 & & TMS \\
\hline Sampel 27 & $\geq 1898$ & & TMS & 7 & & TMS \\
\hline Sampel 28 & $\geq 1898$ & & TMS & 7 & & TMS \\
\hline Sampel 29 & $\geq 1765$ & & TMS & 46 & & TMS \\
\hline Sampel 30 & 438 & & TMS & 46 & & TMS \\
\hline
\end{tabular}

Keterangan : TMS : Tidak Memenuhi Syarat dan Sehat (PHBS) di Rumah tangga agar terhindar dari penyakit water borne diseases.

Dalam pelaksanaan program ini kami didukung penuh oleh kepala kelurahan Pasayangan Barat, tokoh masyarakat, petugas puskesmas setempat dan semua warga desa Pasayangan Barat pada umumnya. Mereka saling bersinergi demi terlaksananya kegiatan tersebut di Desa Pasayangan Barat.

\section{Pembahasan}

Sebelum merecanakan kegiatan ini, kami melakukan proses observasi dengan kepala lurah Desa Pasayangan Barat setempat dan masyarakat disekitar. Pada tanggal 26 September 2017 dilaksankan proses observasi selanjutnya yang dilakukan adalah perkenalan staf kelurahan dan ke puskesmas Martapura 2 untuk izin ingin melakukan pengabdian kepada masyarakat. Tahap selanjutnya silahturahmi ke rumah beberapa masyarakat. Dalam proses observasi tim kami melaksanakan tahap discovery adalah proses pencarian yang mendalam tentang beberapa hal yang mereka keluhkan tetang kualitas air yang mereka konsumsi. Proses ini dilakukan dengan wawancara appresiatif. Dari proses ini terungkaplah keluhan-keluhan yang dirasakan masyarakat terhadap konsumsi air.

Selanjutnya tim kami merencanakan akan melakukan uji kualitas air sumur gali yang mereka gunakan untuk menganalisis beberapa keluhan mereka terhadap konsumsi air tersebut. Setelah beberapa hari mendapatkan hasil uji laboraturium kualitas air, tim kami segera melaporkan kepada kepala lurah untuk segera melakukan penyuluhan kepada masyarakat terhadap informasi hasil uji laboraturium yang telah kami lakukan sebelumnya.

Berdasarkan hasil laboraturium, bahwa 30 sampel air sumur gali didapatkan hasil untuk kandungan MPN coliform melebihi baku mutu air yang telah ditentukan oleh Peraturan Meteri Kesehatan RI No. 416/Menkes/Per/IX/1990 yaitu 75 s.d $\geq 1898$ MPN/100ml air, semua air responden untuk menyimpan air minum mereka (Yonathan, D, Y, 2013)

Hal ini disambut baik dan antusias tinggi oleh masyarakat karena mereka telah lama ingin mengetahui bagaimana kualitas air pada sumur yang mereka konsumsi karena ada sebagaian masyarakat pernah mengalami penyakit water borne disease salah satunya penyakit diare dan thypus.

Tahap selanjutnya adalah penyuluhan/ sosialisasi. Dalam pelaksanaan penyuluhan diluardugaan banyaknya masyarakat yang hadir dalam acara penyuluhan ini dengan jumlah 40 masyarakat hal ini dikarenakan masyarakat ingin mengetahui hasil kualitas air yang mereka konsumsi, dalam sesi tanya jawab banyak masyarakat saling bertanya salah satunya pertanyaan bagaimana memasak air yang benar, cara menampung air yang benar dan apa yang terjadi apabila kualitas air yang telah di uji kualitasnya melebihi ambang batas serta cara menghindari terkenanya penyakit water borne diseases. Serta Kami mempraktekkan bagaimana cuci tangan pakai sabun yang benar yang sesuai indikator Perilaku Hidup Bersih dan Sehat (PHBS) di rumah tangga. Setelah mengetahui hasil program pengabdian masyarakat berupa Peningkatan Perilaku Hidup Bersih dan Sehat (PHBS) di Rumah Tangga dalam Penggunaan Air Sumur Gali dalam menurunkan angka kejadian Water Borne Disease di Desa Pasayang Barat Kabupaten Banjar dengan pendekatan PRA (Participatory Rural Appraisal) diatas, maka berikut ini diuraikan tentang dampak terlaksananya program pengabdian tersebut bagi masyarakat di kelurahan Pasayangan Barat. 
Dampak bagi masyarakat, dengan terlaksananya program pengabdian berupa perubahan Perilaku Hidup Bersih dan Sehat (PHBS) dalam penggunaan air sumur gali dan kesadaran masyarakat terhadap konsumsi air untuk keperluan sehari-hari agar terhindar dari penyakit water borne diseases. Dengan demikian dapat dikatakan kami dapat merubah perilaku masyarakat terhadap konsumsi air.

\section{Kesimpulan}

Dari hasil pelaksanaan dan pembahasan peningkatan Perilaku Hidup Bersih dan Sehatn (PHBS), maka dapat disimpulkan bahwa :

Pengetahuan masyarakat mengenai Perilaku Hidup Bersih dan Sehat (PHBS) di rumah tangga sebelum diberikan penyuluhan masih sangat minim. PHBS yang dilakukan masyarakat sebelum mengikuti penyuluhan belum diterapkan dengan baik dalam hal pengelolaan air. Karena melihat kondisi dan kemampuan masyarakat tentang PHBS pada umumnya belum mengetahui PHBS yang benar, padahal PHBS sangat penting di rumah tangga.

Kegiatan Penyuluhan Peningkatan Perilaku Hidup Bersih dan Sehat (PHBS) dilaksanakan melalui metode PRA (Participatory Rural Appraisal) atau penilaian masyarakat secara partisipatif. penyuluhan terhadap masyarakat sesuai dengan pendekatan PRA yaitu mulai dari proses observasi dan silahturahmi terhadap masyarakat apa yang mereka alami terhadap konsumsi air sumur gali

Setelah diberikannya kegiatan Penyuluhan Peningkatan Perilaku Hidup Bersih dan Sehat (PHBS) diharapkan dapat diterapkan di kehidupan sehari-hari dengan baik dan benar untuk mencegah water borne diseases berbasis rumah tangga.

\section{Ucapan Terimakasih}

Kami sangat berterima kasih kepada UPT. Laboraturium Kesehatan Dasar Air Kabupaten Banjar, Kantor Kelurahan Pasayangan Barat, Puskesmas Martapura 2 dan Badan Kesbangpol Kabupaten Banjar karena di izinkan untuk melakukan pengabdian masyarakat serta saya mengucapkan terima kasih kepada masyarakat sebagai peserta pengabdian masyarakat ini.

\section{Daftar Pustaka}

Departemen Kesehatan RI., 1990. Peraturan Menteri Kesehatan RI No 16/Menkes/Per/IX/1990.Jakarta.

Departemen Kesehatan RI. 2013. Peraturan Menteri Kesehatan Republik Indonesia Nomor 2269/Menkes/Per/Xi/2011 Tentang Pedoman Pembinaan Perilaku Hidup Bersih Dan Sehat .Jakarta.

Departemen Kesehatan RI. 2005. Perilaku Hidup Bersih dan Sehat. Bakti Husada:Jakarta.

Devi, N. Hubungan kondisi fasilitas sanitasi dasar dan personal hygiene dengan kejadian diare di Kecamatan Semarang Utara Kota Semarang. 1, 922-933 (2012).

I.A.M.Trisnawulan, Suyasa, I. W. B. \& Sundra, I. K. Analisis Kualitas Air Sumur Gali di Kawasan Pariwisata Sanur. Ecotrophic 2, 1-9 (2007).

Kementerian Kesehatan. Peraturan Menteri Kesehatan RI 416/MENKES/PER/IX/1990 terntang syarat-syarat dan Pengawasan Kualitas Air. 1-10 (1990).

Mukono, J. 2002. Epidemiologi Lingkungan. Surabaya; Airlangga University Press

Puspita, Sari dan Mukono J. 2013. Hubungan Kualitas Bakterologis Air Sumur dan perilaku Sehat dengan Kejadian Water Borne Disease di Desa Tambak Sumur Keamatan Waru Kabupaten Sidoarjo. Jurnal Kesehatan Lingkungan Vol 7 No 1 JuLI 2013 76-82 (Diakses Tanggal 28 Oktober 2017)

Wulandari, S., Siwiendrayanti, A. \& Setyo Wahyuningsih, A. Higiene Dan Sanitasi Serta Kualitas Bakteriologis Damiu Di Sekitar Universitas Negeri Semarang Info Artikel. UJPH Unnes J. Public Heal. 4, 8-15 (2015).

Yonathan, D. Y. Hubungan antara kualitas sarana \& prasarana rumah dan perilaku sehat dengan kejadian demam typhoid di wilayah kerja puskesmas Ngaliyan Kota Semarang. J. Kesehat. Masy. 2, (2013) 